\title{
The Need for The Integration of Enterprise Characters Through Virtual Fashion Show in The Pandemic Period
}

\author{
Sri Endah Wahyuningsih ${ }^{1}$, Trisnani Widowati ${ }^{2}$, Sicilia Sawitri $^{3}$, A Widyanti $^{4}$, AR Pratiwi ${ }^{5}$ \\ \{s.endah32@mail.unnes.ac.id, niwid272@gmail.com, siciliasawitri@mail.unnes.ac.id, \\ Astriwidya007@yahoo.com, Ayuretno67@gmail.com\}
}

Department of Home Economic Education, Faculty of Engineering, Universitas Negeri Semarang, Indonesia $^{12345}$

\begin{abstract}
This study aims to describe empirically how the appropriate work degree model in this pandemic period and the need for developing an integrated entrepreneurial model in the fashion work degree course. Research is carried out through a research and development (R\&D) approach. The method of collecting data online is by questionnaire via google form, chat and zoom, while offline is through discussion. The data were analyzed by descriptive qualitative and percentage descriptive. The results showed that $72.46 \%$ of students and lecturers had a very high need in the category of entrepreneurial integrated fashion virtual work degree models, and were also supported by the results of discussions, face to face and online through chatting and zooming with university leaders, faculty, department managers and lecturers and PKK majors. The research conclusions show that there is a very high level of need for an integrated virtual work title model for entrepreneurship during the Covid-19 pandemic. Suggestions Virtual work titles can be held not only via YouTube but can be combined with zoom meetings.
\end{abstract}

Keywords: Enterprise Characters; Virtual Fashion Show; Pandemic Period

\section{Introduction}

Doing business or entrepreneurship is one option that can overcome the challenges of the industrial revolution 4.0 , especially to reduce high unemployment. So, it is necessary to increase the number of entrepreneurs, especially among millennial entrepreneurs aged 17-37 years. Data The number of entrepreneurs in 2017 only reached $3.31 \%$ of Indonesia's population, while the World Bank standard is $4 \%$. Compared to other ASEAN countries, the number of Indonesian entrepreneurs is also smaller, for example Singapore (7\%), Malaysia $(5 \%)$, and Thailand (4.5\%), and is not much different from Vietnam $(3.3 \%)$. (KEMENKOP UKM, 2017). Currently the position of Indonesia's competitiveness ranking is also worrying, where Indonesia's ranking has dropped from 45 to 50 and lost to neighboring countries, namely Singapore, which was ranked first, beating America and other European countries, where Singapore was named the most competitive economy in the world for the public sector, workforce, diversity, and infrastructure (World Economic Forum, 2019).

UNNES is one of the universities that is planning to become an independent university or known as PTBHMN in 2020 so that entrepreneurship education and innovation development are priority programs developed by Unnes. Entrepreneurship and innovation are among the 
flagship programs of UNNES and the Faculty of Engineering in particular to prepare graduates with entrepreneurial characteristics and produce creative and innovative products. Work degree courses are a continuation of practical courses and courses in entrepreneurship and business management.

FT UNNES has a FT performance target in 2020 to increase the number of entrepreneurs. This condition needs to be followed up so that all the potential possessed by students, lecturers, and students can be developed optimally in supporting character education and increasing the number of entrepreneurs. Entrepreneurship and innovation are among the flagship programs of UNNES and the Faculty of Engineering in particular to prepare graduates with entrepreneurial characteristics and produce creative and innovative products so that they become downstream products and produce creative and innovative products. Work degree courses are a continuation of practical courses and courses in entrepreneurship and business management.

FT UNNES has a FT performance target in 2020 to increase the number of entrepreneurs. This condition needs to be followed up so that all the potential possessed by students, lecturers, and students can be developed optimally in supporting character education and increasing the number of entrepreneurs. Entrepreneurship and innovation are among the flagship programs of UNNES and the Faculty of Engineering in particular to prepare graduates with entrepreneurial characteristics and produce creative and innovative products so that they become downstream products

PKK graduate students, prepared as prospective teachers, can work in industry and can become entrepreneurs. Many students are provided with compulsory courses, one of which is the Work Degree course. The work degree course is the flagship of the PKK department and as the pinnacle of work in the practical courses of the Fashion Design education study program, culinary education program, Beauty education study program and Family Welfare Education study program. The title of work courses has been carried out simultaneously in one PKK department in 1 activity in the form of exhibitions and demonstrations. Products of work degree courses and works degree courses are not sold to the public or consumers.

The implementation of work degree courses can be held because of the collaboration of all parties, it is a collaboration of 4 study programs, requires a high enough cost, extra manpower, a lot of human resources so that the right strategy is needed so that this work degree activity can not only be held and cancels course obligations. If the course of work degree is better designed, it will bring many invited guests so that as a promotion for the study program, it will get a lot of sponsors, get ticket sales, product sales, and many partners for cooperation. Existing income can reduce student tuition and replace expenses for products. The course degree of work if packaged properly will foster and provide character education, especially mental forging, and cultivate entrepreneurial skills and experiences, especially to improve work ethic, result orientation, cooperation, leadership, creativity and innovation, care for the advantages of local networking materials and independence.

The form of activities Holding works has been through face-to-face exhibitions and fashion shows to introduce and promote student work products. The product works are not only exhibited directly but also in written form, but have not been optimally utilized and have not been followed up into books with ISBNs and copyright has not been filed. Currently in the 2019 Corona pandemic the PKK department will hold a work title according to routine activities every year in semester 6 . During the pandemic it is prohibited to hold activities that bring crowds, must comply with the SATGAS COVID -19 regulations. Most of the lecturers and students were worried about holding a workshop, so there were several suggestions to postpone its implementation in the next semester. There are differences in how to respond, and 
the interests of work degree courses must be maintained so that student studies are not delayed, and the pandemic is a challenge but also an opportunity so that empirical research needs to be carried out related to the development of an appropriate work degree model in this pandemic and can improve the entrepreneurial character of students.

Therefore, empirical research is needed on the need to develop an integrated model of entrepreneurial character in the subject of fashion work through virtual fashion modeling.

\section{Methodology}

\section{Approach}

The chosen procedural model adopted from the research and development model of Borg and Gall (2003: 571), and the procedural model design developed by Sugiyono (2012: 298) and Rachman (2011: 266) that in the implementation of research and development (research and development ( $\mathrm{R} \& \mathrm{D}$ ) includes ten steps, namely: (1) research and data collection (analysis of needs and objectives), (2) planning, (3) developing product drafts, (4) initial field trials, (5) revising test results trials, (6) field trials, (7) field testing product improvement, (8) field implementation testing, (9) final product improvement, and (10) dissemination and implementation. Meanwhile Sugiyono (2012: 298-311) describes ten steps of research and development as follows: (1) potential and problems, (2) data collection, (3) product design, (4) design validation, (5) design improvement, (6) product testing, (7) product revision, (8) use trial, (9) product revision, and (10) mass production.

\section{Data Collection Methods}

The data collection method was obtained through discussion / FGD and questionnaires. The FGDs were conducted offline and online. Discussions related to the theme, technical implementation of the work degree were carried out in the PKK department together with department managers, a team of lecturers and student representatives while in the dean building by presenting all students. Discussion forums of virtual work degree models are carried out online through chats in groups of lecturers majoring in colleagues, groups of lecturers who hold work degrees, groups of lecturers and students with work degrees, and zoom meetings by presenting university leaders, faculty managers and department managers, zoom meetings with FT managers and management of the PKK department, zoom meeting with the committee, lecturers and student representatives.

Questionnaires are taken online via Google.Form, questions using a scale of $1-5$ to obtain interval data. Questioner questions reveal the need about: The importance of entrepreneurship integration, the need to develop a virtual work model, benefit aspects for promotion, marketing, networking, independent training, increasing competence, organizational training, and communication or networking. The answer to each instrument item that uses a Likert scale has a gradient from very positive to very negative, which can be in the form of words such as: number 1 to express the respondent's opinion "Strongly Disagree" while number 5 to express the respondent's opinion "Strongly Agree".

The population consisted of lecturers and students of the PKK Department of Fashion Design education at the Faculty of Engineering, UNNES. The sample consisted of 69 students of fashion design education study program class 2017, 2016 and lecturers of fashion design education study program. The sample size was determined randomly. The number of samples is based on the Herry King and Krischi charts with an error rate of 5\%. 
Data Analysis Techniques used Qualitative and quantitative descriptive analysis (percentage description) to describe the needs of students and lecturers related to the development of a virtual work degree model of integrated entrepreneurial fashion. The data from the questionnaire in this study is quantitative data which will be analyzed descriptively in percentages by following Ridwan's (2004: 71-95) steps: 1. Calculating the value of the respondent and each aspect or sub variable. 2. Recap the value. 3. Calculate the average value. 4. Calculating the percentage using the formula: Information: DP $=$ Descriptive Percentage (\%) $\mathrm{n}=$ empirical score (score obtained) $\mathrm{N}=$ maximum score of the question item Research result Description of the need for a virtual and integrated entrepreneurial degree of work This semester's Degree of Work course is different from last year's semester because the work degree was held during the Covid-19 pandemic.

The work degree course is a compulsory subject and has been issued in the study plan to be achieved in the even semester of 2020. During the Covid 19 pandemic, it has regulations according to conditions so that everyone remains healthy and does not spread the virus so all activities must be packaged with new innovations because they are not allowed to organizing activities that invite both physical and social crowds. The event is very close to character because it demands the work ethic of all parties so that the work can be organized well, can bring a lot of invited guests as well as spending efficiency and effectiveness. The implementation of the work degree shows the creativity and innovation of all levels, both managers, lecturers and students.

The current condition of the Covid pandemic cannot be met until when it ends, while learning activities must continue and should not be delayed so that it hinders the student learning process so a strategy or model effective administration so that the 4 study program degree courses continue to run smoothly, and are not delayed. Based on dialogues and discussions with students, lecturers, departmental lecturers, department managers, faculty managers, and university leaders face-to-face, through chat, and through zoom, it was decided it was necessary to continue holding titles according to health protocols through virtual fashion shows for clothing using YouTube page majoring PKK.

\section{Result and Discussion}

Description of the need for a virtual and integrated entrepreneurial degree of work This semester's Degree of Work course is different from last year's semester because the work degree was held during the Covid-19 pandemic. The work degree course is a compulsory subject and has been issued in the study plan to be achieved in the even semester of 2020 . During the Covid 19 pandemic, it has regulations according to conditions so that everyone remains healthy and does not spread the virus so all activities must be packaged with new innovations because they are not allowed to organizing activities that invite both physical and social crowds. The event is very close to character because it demands the work ethic of all parties so that the work can be organized well, can bring a lot of invited guests as well as spending efficiency and effectiveness.

The implementation of the work degree shows the creativity and innovation of all levels, both managers, lecturers and students. The current condition of the Covid pandemic cannot be met until when it ends, while learning activities must continue and should not be delayed so that it hinders the student learning process so a strategy or model effective administration so that the 4 study program degree courses continue to run smoothly, and are not delayed. 
Based on dialogues and discussions with students, lecturers, departmental lecturers, department managers, faculty managers, and university leaders face-to-face, through chat, and through zoom, it was decided it was necessary to continue holding titles according to health protocols through virtual fashion shows for clothing using YouTube page majoring PKK. The level of need for a virtual work degree model in a pandemic and integrated entrepreneurial period the following is a table and picture of the overall histogram. The level of needs of lecturers and students of entrepreneurial character integration models in work degree courses through virtual fashion shows.

Based on the table and histogram above, it shows that $72.46 \%$ of the needs of students and lecturers are in the very high category and $27.54 \%$ in the high category, thus it can be concluded that the majority of students and lecturers who are able to hold a Fashion Title in the PKK FT UNNES department have a need for a work degree model. virtual integrated entrepreneurship in times of pandemic is very high

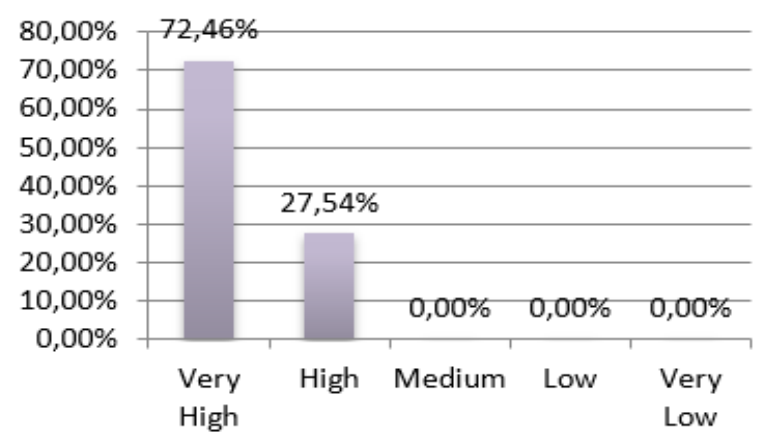

Fig 1. Histogram Description of the needs of the overall integrated entrepreneurial virtual work degree model

The description of the lecturer's needs can be seen in the picture histogram 2 , it can be illustrated that the lecturers' needs for the need for entrepreneurial integration and the virtual work degree model are $70,21 \%$ of the lecturers strongly agree, $29,79 \%$ agree.

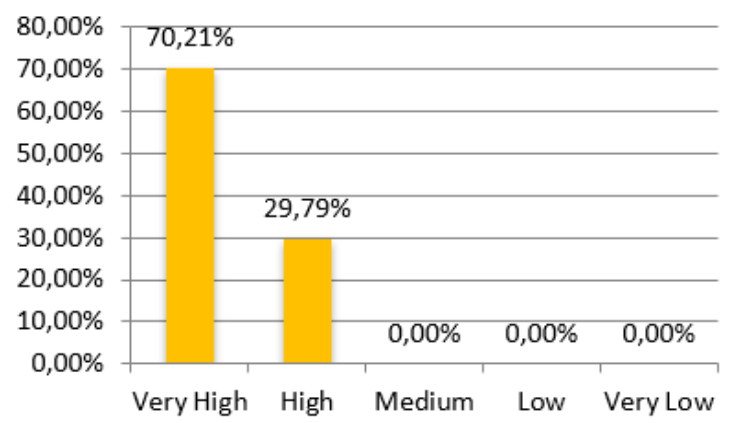

Fig 2. Histogram Description of the needs of the overall integrated entrepreneurial virtual work degree model 
The following picture of histogram 3 can be illustrated. Description of the needs of students in class 2016 for integration of entrepreneurship and virtual work degrees shows $77.78 \%$ strongly agree and $22,22 \%$ agree.

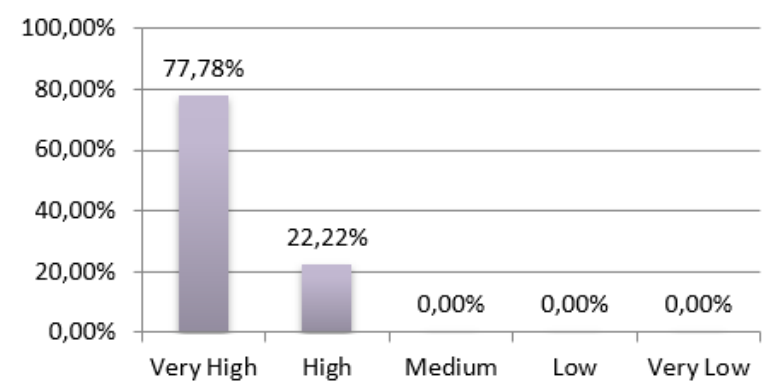

Fig 3. Histogram Description of the needs of an integrated entrepreneurial virtual work degree model as a whole

The description of the needs of the 2017 fashion design education study program students who are currently pursuing a work degree shows that $70.21 \%$ strongly agree and $29.79 \%$ agree that students need entrepreneurial integration and virtual development of work degree models. The following is a histogram image:

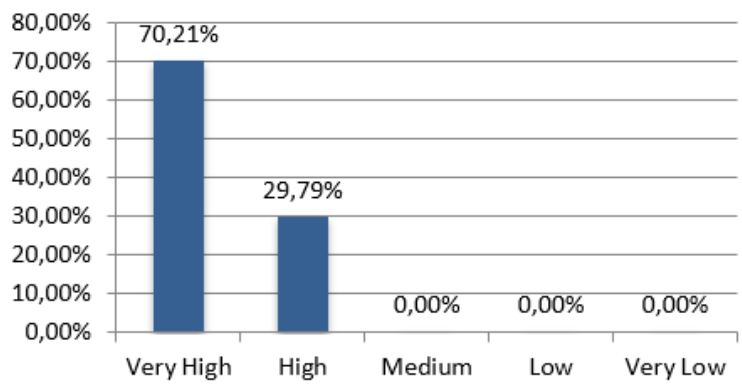

Fig 4. Histogram Description of the students' entrepreneurial integration-oriented virtual work degree model requirements

The results showed that there was a very high need for a virtual work degree model and integrated entrepreneurship by students and lecturers of the fashion education study program and also very high support from higher education leaders, faculty managers and department managers as well as PKK department lecturers. The current fashion work titles are different from the previous year, the work titles during the pandemic were held virtually by broadcasting a fashion video show of all the students participating in the 2017 Class Fashion Work Degree course which was broadcast live streaming through the you tube channel, PKK. The current event takes the theme GLOCAL (global local), the development of fashion products towards the era of 5.0. GELARKARYA fashion products use local materials and ideas in order to be able to go global.

This is in accordance with the research of Rui Hou Huanghe (2015) in the Science and Technology College of Zhengzhou, China at the International Conference on Arts, Design and Contemporary Education (ICADCE 2015) Presenting his work on an analysis on Commercial and Cultural Functions of Fashion Show Spread that fashion works in the form of fashion 
shows is a communication activity through information transmission and social and cultural transmission. Fashion shows play a large role in cultural transmission as public "gatekeepers". Fashion shows, also play the role of "opinion leader" models, directors, etc. play positive and negative roles, actively and passively in social and cultural transmission.

There is a need for an integration model of entrepreneurship and a virtual work title, the research result is in accordance with the research results of Sri Endah Wahyuningsih, at all (2018: 448) that for the education of prospective fashion teachers, it is necessary to develop models and implement management of entrepreneurship education based on local excellence. This is also in accordance with the results of Ni Desak Made's (2014) research on the ProjectBased Learning Model $(\mathrm{Pbp})$ in the Cipta Karya course to Foster Entrepreneurship for Students of the Pkk Department, showing that the process of completing work degree products through the application of creative project-based learning models can foster an entrepreneurial spirit. which was categorized as very good with an average score of 83.6.

Fashion show models during the pandemic are no longer held in buildings, and there are no large crowds, do not consume a lot of consumption, and can be seen at any time without being limited by space and time via YouTube. This is supported by Xing Gao (2018: 483) about a virtual fashion show that can use the unity 3D software system and $3 \mathrm{~d}$ Max to model stage scenes, lighting, music and character models, clothing to reproduce the real stage maximally which can give users a level of engagement. high. This was also supported by Louise Crewe. (2013: 760) argues about When Virtual and material Worlds collide: Democratic Fashion in The Digital Age that the fashion space is increasingly portable and as the transformative effect of digital mode is explored. The network effect of the internet allows no need for a physical presence, and is limited by space, with the internet allowing the creation of a community that is always active and connected. The collision between virtual and material modes of space requires fundamental thinking about the roles of fashion production, consumption, knowledge and basic law.

The results of the research that showed the very high need for virtual work degrees by PKK students and lecturers were also supported by Soyeon Kim. According to Soyeon Kim (2018: 12) regarding Virtual Exhibitions and Communication Management Factors in the journal Museum Management and Curatorship, it is explained that virtual exhibitions are an effective, strong communication medium with great potential and unique opportunities to promote and influence visitors. Virtual exhibits not only reproduce and transfer physical exhibits but also actualize new ones and create new dimensions of virtual exhibits and interaction spaces to provide an informative and entertaining user experience through effective communication means or strategies. Overall, social media is bringing about a fundamental shift in the relationship between the two museums and visitors, moving towards a more interactive and collaborative form. In particular, social media has made it possible to engage individuals and communities in original and innovative two-way or multi-way communication (Russo et al. 2008; Fletcherd and Lee 2012).

\section{Conclusion}

The conclusion of this research is that there is a very high need of lecturers and students as well as the support of higher education leaders so that virtual work degrees and integrated entrepreneurship can be held. Currently, virtual work titles are broadcast only through You Tube channels, in the future it can be combined with zoom meetings. 


\section{References}

[1] G. Knight, "Entrepreneurship and marketing strategy: The SME under globalization,” J. Int. Mark., vol. 2, p. 12-21, 2000.

[2] L. Crewe, "When virtual and material worlds collide: Democratic fashion in the digital age," Environ. Plan. A, vol. 45, p. 760-780, 2013.

[3] B. K. Daniel Motidyang, "A Bayesian belief network computational model of social capital in virtual communities," 2007.

[4] A. Abou-Moghli and A. Al Muala, "Impact of Entrepreneurial Networks in the Success of Business on-Going Stage in Jordanian Manufacturing Companies,” Am. Acad. Sch. Res. J., vol. 4, no. 2, p. 76-91, 2012.

[5] S. F. Slater and E. M. Olson, "Marketing's contribution to the implementation of business strategy: An empirical analysis," Strateg. Manag. J., vol. 22, no. 11, 2001.

[6] T. S. Agustina, "Peran Inkubator Bisnis Perguruan Tinggi Dalam Meminimalkan Resiko Kegagalan Bagi Wirausha Baru Pada Tahap Awal (Start-Up)," Majalah Ekonomi, 2011.

[7] S. E. Wahyuningsih, Sugiyo, S. Samsudi, T. Widowati, and A. Kamis, "Model of local excellence-based on entrepreneurship education management for prospective vocational school teachers," vol. 24, no. 4, 2018.

[8] Suwandi, "Pengembangan Model Inkubator Bisnis Perguruan Tinggi," vol. 12, no. 2, p. 65-86, 2007.

[9] X. GAO, M. CHEN, S. GUO, W. SUN, and M. LIAO, "Virtual Fashion Show with HTC VIVE," DEStech Trans. Mater. Sci. Eng., no. icmsa, pp. 483-488, 2018.

[10] S. Kim, "Virtual exhibitions and communication factors," Museum Manag. Curatorsh., 2018.

[11] A. Russo, J. Watkins, L. Kelly, and S. Chan, "Participatory Communication with Social Media," Curator Museum J., 2008.

[12] Ernani Hadiyati, "Kreativitas dan Inovasi Berpengaruh Terhadap Kewirausahaan Usaha Kecil," J. Manaj. dan Kewirausahaan, vol. 13, no. 1, 2011.

[13] A. Fletcher and M. J. Lee, "Current social media uses and evaluations in American museums," Museum Manag. Curatorsh., 2012.

[14] W. Borg dan M. Gall, Educational Research: An Introduction 4th Edition, London: Longman Inc, 2003.

[15] P. Kotler, Marketing Management -Analysis, Planning, Implementation and Control, New Jersey: Prentice Hall International, Inc, 2006.

[16] P. Murwatiningsih dan Hengky, Meningkatkan Kinerja Pemasaran Melalui Kapabilitas Bisnis Unggul Dan Jejaring Kewirausahaan, Laporan Penelitian Unnes, 2015.

[17] M. Rachman, Metode Penelitian Pendidikan Moral dalam Pendekatan Kuantitatif, Kualitatif, Campuran, Tindakan, dan Pengembangan, Semarang: UNNES Press, 2011.

[18] M. Sugiyono, Metode Penelitian Kuantitatif R\&D, Bandung: Alfabeta, 2012.

[19] N. D. M. S. Adnyawati, "Inovasi Pembelajaran Proyek Berbasis Budaya Lokal Untuk Meningkatkan Kreativitas Pembelajaran Tata Graha," INVOTEC, vol. 10, no. 2, pp. 111-120, 2014.

[20] R. Hou, "An analysis on Commercial and Cultural Functions of Fashion Show Spread," International Conference on Arts, Design and Contemporary Education, pp. 512-514, 2015. 